\title{
Comparative Study of Understory Between Exotic Monoculture Plantation (Acacia Sp.) and Adjacent Natural Sal (Shorea Robusta) Forest
}

\author{
Md. Tauhidor Rahaman, D. B. Gurung, and Md. Najmus Sayadat Pitol
}

\begin{abstract}
To achieve forest management goal it is important to maintain biodiversity. This paper compares understory plant species diversity between exotic monoculture plantation (Acacia auriculiformis) and adjacent natural sal (Shorea robusta) forest. A total of 35 sample plots were taken by random sampling from six patches of adjacent natural sal forest and exotic monoculture plantation. Shannon-Wiener diversity index, species richness and evenness were calculated and compared. Result revealed that, a total of 2,218 plants of 42 species were recorded in natural sal (Shorea robusta) forest. Dominant families were Apocynaceae and Verbanaceae, having three species in each family. Shannon-Wiener diversity index was 2.1 and mean species richness was 14.4. On the contrary, 2,827 plants were found from 15 species in exotic monoculture (Acacia auriculiformis) plantation study area. Dominant family was Leguminosae family. Three species were found under Leguminosae family. Shannon-Wiener diversity index was 0.86 and mean species richness was 4.47. Therefore, Shannon diversity index and richness were significantly higher in natural sal forest as compared to exotic monoculture plantation. Species evenness of natural sal forest was 0.8 and 0.6 for monoculture plantation which indicates less equitable distribution of understory vegetation in monoculture than adjacent natural sal forest. With regard to herb species, evenness was significantly lower in monoculture plantation $(0.03)$ as compared to natural sal forest $(0.52)$. There was no equitable distribution for the herb species under monoculture plantation. Jaccard's similarity index showed that $36 \%$ shrub species and $30 \%$ of herb species were same in exotic monoculture plantation area and adjacent natural sal forest.
\end{abstract}

Index Terms - Herb, shrub, species diversity, species evenness, species richness.

\section{INTRODUCTION}

Monoculture plantation is defined as the plantation using single species of same age, first growing and short rotation [1]. The equivalent row detachment and clear felling system is practiced in order to simplify better harvesting in this plantation [2]. According to Harley [3], currently 3\% of the world's forests are plantation forest containing 60 million hectares in developed and 55 million hectares in developing countries. It is scattering across the world to convey raw materials and replacing native forest. In Bangladesh, monoculture plantation program is increasing annually, and the exotic species are gaining preferences over the native one [4]. Bangladesh government is trying to reforest the area with some fast-growing exotic species [5] and about $70 \%$ of the plantation area is planted with exotic. Most extensively planted exotic in natural sal forest area are Acacia

Published on December 31, 2020.

Md. Tauhidor Rahaman.

(e-mail: tauhidor.rahaman ${ }^{\circledR}$ gmail.com)

D. B. Gurung. auriculiformis, Acacia mangium and Eucalyptus camaldulensis which are $26.1 \%, 18.7 \%$ and $24.6 \%$ respectively [6]. In spite of prospect to manage natural sal forest, coppices were clear felled in many places to make way for commercial monoculture plantations with exotic species even the root was uprooted.

Sal forest is the only major natural forest resource of the central and northern part of Bangladesh [7, 8]. The majority sal forests are distributed in Gazipur, Tangail and Mymensing district [9]. Bangladesh has only 17.5\% (2.52 million hectares) forest cover and the sal forest covers about $4.7 \%$ translating to 0.12 million hectares [7], [10]-[13]. It was reported that more than $60 \%$ of the sal forests were densely wooded in the late 1970 s whereas about $38 \%$ of the sal forest cover existed in 1985 and $10 \%$ in 1990 [14]. Sal forest is the most vulnerable ecosystem of Bangladesh [13]. The rapid expansion of agriculture and monoculture plantation is a significant threat to the understory plant species diversity, and it has been rapidly exhausted in recent times due to rubber monoculture plantation and expanding commercial woodlot plantation [5]. Over the last forty years, the sal forests have shrunk drastically due to new plantation with exotic [6]. About 16,000 hectares of natural sal forest have been exchanged with woodlots monoculture plantation under Dhaka forest division [15], [16]. In Modhupur sal forest (under Tangail forest division), out of 18,623.48 hectares forest land 3157.89 hectares were assigned for rubber plantation. Another 40,000 hectares of sal forest were planned for monoculture plantation and agro forestry plantation in Tangail forest division under forestry sector project [17]. Plantation forestry is one of the biggest threats to the understory species diversity of natural sal forest [11].

The yield of plantation forest is a part of the economic growth and such economic growth should not be hampered by a lack of ecological information. It is important to quantify the connotation of exotic monoculture plantation with understory species diversity in order to ensure sustainable forest management. This document will flag and illustrate on the understory vegetation effect of exotic monoculture plantation, with a special emphasis in context of Gazipur, Bangladesh. This research will focus on the comprehensive ecological study encompassing understory species diversity, which has not been done till date in the study area. Although the replacement of sal forest by exotic monoculture plantations still increasing [13] which leads to disappearing of understory plant species diversity [18, 19]. Therefore, a comparative study to assess the understory plant

(e-mail: dbgurung.crn ${ }^{\circledR}$ rub.edu.bt)

Md. Najmus Sayadat Pitol.

(e-mail: najmus.sayadat ${ }^{\circledR}$ gmail.com) 
species diversity in exotic monoculture plantation and natural sal forest was felt necessary as stressed by Rahman et al. [5]. The aim of this study is to quantify understory species diversity and to assess the vegetation layer in exotic monoculture plantation and adjacent natural sal forest.

\section{MATERIALS AND METHODS}

\section{A. Study Site}

The study site is located at Kaliakair Upazilla under Gazipur district in Bangladesh. Exotic monoculture plantation (EMP) and the adjacent natural sal forest (NSF) were determined at Bualy beat office area under Kaliakair range. Latitude is $24^{\circ} 0920^{\prime \prime}$, longitude is $90^{\circ} 15^{\prime} 34^{\prime \prime}$ and altitude lies between $6 \mathrm{~m}$ to $34 \mathrm{~m}$ above the sea level. Study areas fall into mid-south region [9]. The average annual temperature of the study area is $19.9{ }^{\circ} \mathrm{C}$ [20]. The average relative humidity lies from $70.5 \%$ to $78.51 \%$. Rainy season (June through October) accounts for $70-85 \%$ of the annual rainfall and an average of $181 \mathrm{~mm}$ [20] precipitation.

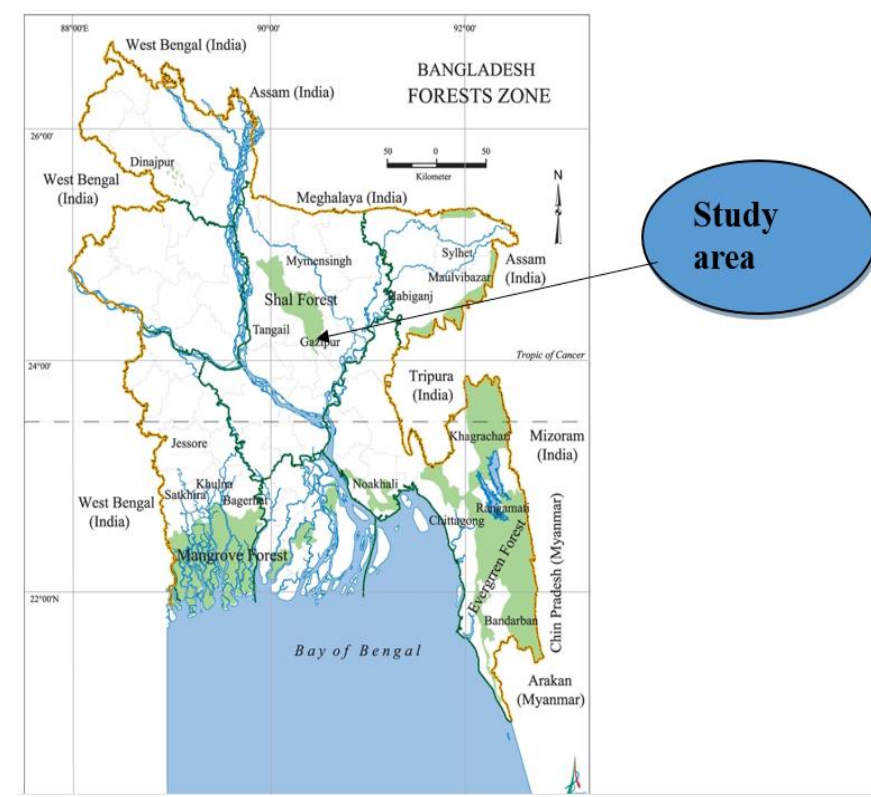

Fig. 1. Forest map of Bangladesh (sal forest lies in central part) (Source: Banglapedia).

\section{B. Survey Method and Sampling Design}

\section{Sampling design}

In order to generate representative data, six adjacent patches of natural sal forest and Acacia auriculiformis monoculture plantation were sampled. Data were collected applying random sampling. Reference point in each patch of forest was selected randomly and plot to plot distance of 100 $\mathrm{m}$ was maintained on the longest transect of each patch. Quadrats of $10 \times 10 \mathrm{~m}$ were designed to enumerate understory plant species. Out of 35 sample plots surveyed, 17 were in exotic monoculture plantation and 18 in adjacent natural sal forest.

\section{Methods}

One of the most commonly used measures of species diversity is the Shannon-Wiener diversity index. The higher number indicates higher species diversity. Species diversity index $\left(\mathbf{H}^{\prime}\right)$ was calculated by using Shannon-Wiener diversity Index [21].

$$
\begin{aligned}
& \mathrm{H}^{\prime}=-\sum_{i=1}^{s} P i(\operatorname{LnPi}) \\
& P i=\frac{n i}{N}
\end{aligned}
$$

where,

$\boldsymbol{n i}=$ Number of individuals of species".

$\mathbf{N}=$ Total number of individuals of all species.

$\boldsymbol{P} \boldsymbol{i}=$ Relative abundance of species " ".

$\boldsymbol{S}=$ Total number of species.

$\mathbf{H}^{\prime}$ = The Shannon-Wiener diversity index.

Species evenness was calculated to assess the equitability or evenly distribution pattern of different understory species. Evenness index ranges from 0 to 1 , where 0 signifying no evenness and 1 signifying complete evenness.

\section{Evenness index e $=H^{\prime} / \ln (S)$}

where,

$\mathbf{H}^{\prime}=$ Shannon's diversity index.

$\mathbf{S}=$ No. of species (species richness).

The Jaccard's [22] index is a valuable tool because it allows one to determine whether two communities are composed of similar species.

\section{Jaccard index $=\mathbf{A} /(\mathbf{A}+\mathbf{B}+\mathbf{C})$}

where,

$\mathrm{A}=$ Total number of species present in both communities.

$\mathrm{B}=$ the number of species present in community 1 but not 2 .

$\mathrm{C}=$ the number of species present in community 2 but not in 1.

If the Jaccards' index is equal to $1(\mathrm{~B}=0 \& \mathrm{C}=0)$, all species are shared between the two communities and near to 0 , no species are shared between two communities.

\section{Data Analysis}

The preliminary data have been processed using Microsoft Excel spread sheet office 2010. Data compilation and graph were created through Microsoft Excel spread sheet. Analysis was carried out by using SPSS version 16 . Nonparametric Mann-Whitney $U$ test was carried out to determine the mean differences between exotic monoculture plantation and adjacent natural sal forest.

\section{RESULT AND DISCUSSION}

\section{A. Composition of Species in Natural Sal Forest (NSF)}

A total of 2,218 plants were recorded which belong to 42 species in NSF. Among the species, 37 species belong to 26 families. Three species were identified by local name and another two species were unidentified. Dominant families were Apocynaceae and Verbenaceae, having three species in each family. The species composition for Apocynaceae family includes Holarrhena pubescens, Rauvolfia serpentine, Tabernaemontana coronaria species and for Verbenaceae family: Callicarpa arborea, Clerodendrum viscosum and Gmelina arborea. Combretaceae, Euphorbiaceae, Fabaceae, Leguminosae, Myrtaceae, 
Rubiaceae and Rutaceae families had two species each. The remaining 17 families were represented by single species each. Highest number of species richness (22) and diversity (2.62) had been found in plot S3 where lowest numbers of species richness (7) and diversity (1.24) found in plot S16. Mean species richness and mean diversity index were 14.4 and 2.1 respectively. Species evenness was highest in S2 and lowest in S16 which was 0.9 and 0.64 respectively. The mean evenness found for natural sal forest was 0.8 . This indicates that NSF had equitable distribution of the species. Stem density was highest in S1 (265) and lowest in S16 (31) (Table 1).

TABLE 1: PLOT AREA, DIVERSITY, RICHNESS, EVENNESS AND DENSITY OF NATURAL SAL FOREST (NSF)

\begin{tabular}{cccccccccccccccccccc}
\hline Plot ID & S1 & S2 & S3 & S4 & S5 & S6 & S7 & S8 & S9 & S10 & S11 & S12 & S13 & S14 & S15 & S16 & S17 & S18 \\
\hline Plot area (m2) & 100 & 100 & 100 & 100 & 100 & 100 & 100 & 100 & 100 & 100 & 100 & 100 & 100 & 100 & 100 & 100 & 100 & 100 \\
Diversity (H') & 2.3 & 2.43 & 2.62 & 2.1 & 1.77 & 2.59 & 2.49 & 2.29 & 1.68 & 2.24 & 1.92 & 2.3 & 1.81 & 1.99 & 1.67 & 1.2 & 2.11 & 2.1 \\
Richness (Nos.) & 19 & 15 & 22 & 14 & 9 & 22 & 17 & 17 & 11 & 20 & 12 & 17 & 11 & 10 & 10 & 7 & 13 & 14 \\
Evenness (J') & 0.78 & 0.9 & 0.85 & 0.8 & 0.81 & 0.84 & 0.88 & 0.81 & 0.7 & 0.75 & 0.77 & 0.8 & 0.75 & 0.86 & 0.73 & 0.6 & 0.82 & 0.8 \\
Density (Nos.) & 265 & 156 & 240 & 105 & 71 & 199 & 73 & 205 & 65 & 135 & 160 & 175 & 66 & 51 & 78 & 31 & 50 & 93 \\
\hline
\end{tabular}

Note: $\mathrm{S}=$ Sal Sample Plot.

\section{B. Composition of Shrub and Herb Species in Natural Sal Forest (NSF)}

Shrub species were common in study area. A total of 27 shrub species were found. Out of that, 23 shrubs species were found from 18 families and four species family could not be identified. Apocynaceae family had higher number of species (Holarrhena pubescens, Rauvolfia serpentina, Tabernaemontana coronaria). Two species each had been found in Verbenaceae and Rubiaceae family. Another family had single species each. A total of eight herb species were found from six families. Single species were noted each from six families and two species were unidentified.

C. Species Coverage in Natural Sal Forest (NSF) TABLE 2: SPECIES COVERAGE IN NATURAL SAL FOREST

\begin{tabular}{cccc}
\hline Species & Family & $\begin{array}{c}\text { Density } \\
\text { (Count) }\end{array}$ & $\begin{array}{c}\text { Coverage } \\
(\%)\end{array}$ \\
\hline Randia dumentorum & Rubiaceae & 403 & 18.2 \\
Curcuma zeodaria & Zingiberaceae & 239 & 10.8 \\
Clerodendrum viscosum & Verbenaceae & 192 & 8.7 \\
Antidesma sp. & Euphorbiaceae & 184 & 8.3 \\
Microcos paniculata & Tiliaceae & 143 & 6.4 \\
Chromolaena odorata & Asteraceae & 135 & 6.1 \\
Melastoma malabathricum & Melastomataceae & 86 & 3.9 \\
Flacourtia indica & Flacourtiaceae & 86 & 3.9 \\
Litsea monopetala & Lauraceae & 80 & 3.6 \\
Indigofera Tasmania & Leguminosae & 74 & 3.3 \\
Indigofera tinctoria & Fabaceae & 71 & 3.2 \\
Urena lobata & Malvaceae & 65 & 2.9 \\
Tabernaemontana coronaria & Apocynaceae & 59 & 2.7 \\
Ixora spectabilis & Rubiaceae & 56 & 2.5 \\
Calyopteris floribunda & Combretaceae & 50 & 2.3 \\
Callicarpa arborea & Verbenaceae & 35 & 1.6 \\
Rauvolfia Serpentina & Apocynaceae & 27 & 1.2 \\
Thysanolaena maxima & Poaceae & 27 & 1.2 \\
Syzygium fruticosum & Myrtaceae & 25 & 1.1 \\
Terminalia bellirica & Combretaceae & 20 & 0.9 \\
Cordia grandis & Boraginaceae & 14 & 0.6 \\
Phyllanthus embelica & Euphorbiaceae & 13 & 0.6 \\
Holarrhena pubescens & Apocynaceae & 13 & 0.6 \\
Zanthoxylum rhetsa & Rutaceae & 12 & 0.5 \\
Calamas sp. & Palmae & 9 & 0.4 \\
Flemingia bracteata & Fabaceae & 8 & 0.4 \\
Miliusa velutina & Annonaceae & 5 & 0.2 \\
Glycosmis pentaphylla & Rutaceae & 5 & 0.2 \\
Cassia fistula & Caesalpeniaceae & 4 & 0.2 \\
Erioglossum edulis & Sapindaceae & 4 & 0.2 \\
Hyptis suaveolens & Labiatae & 3 & 0.1 \\
Barringtonia acutangula & Lecythidaceae & 3 & 0.1 \\
Mimosa pudica & Leguminosae & 2 & 0.1 \\
Gmelina arborea & Verbenaceae & 2 & 0.1 \\
Phyllanthus reticulatus & Euphorbiaceae & 1 & 0.05 \\
Glycyrrhiza glabra & Fabaceae & 1 & 0.05 \\
Swietenia mahagoni & Meliaceae & 1 & 0.05 \\
Unknown species & & 61 & 2.8 \\
Total & & & 100 \\
\hline & & 2218 &
\end{tabular}

Randia dumentorum species from Rubiaceae family covered $18.2 \%$ of the total vegetation and the density was
403 per $1800 \mathrm{~m}^{2}$ which was highest dominating understory species. Curcuma zeodaria species form Zingiberaceae family represented $10.8 \%$ of the total vegetation and density was 239 per $1800 \mathrm{~m}^{2}$. Clerodendrum viscosum from Verbenaceae family was $8.7 \%$ and density was 192 per $1800 \mathrm{~m}^{2}$. Phyllanthus reticulatus, Glycyrrhiza glabra and Swietenia mahagoni had lowest portion of vegetation cover of the total species which was $0.05 \%$ and density was 1 per $1800 \mathrm{~m}^{2}$ (Table 2).

\section{Life Forms of Natural Sal Forest (NSF)}

Tree, shrub, annual herb, and grass have been found in NSF study area. Study site was dominated by shrub species. Shrub species were representing $73 \%$ of the total species. Annual herb and tree were representing $18 \%$ and $7 \%$ respectively of the total species. Grass was representing $2 \%$ of the total species (Fig. 2).

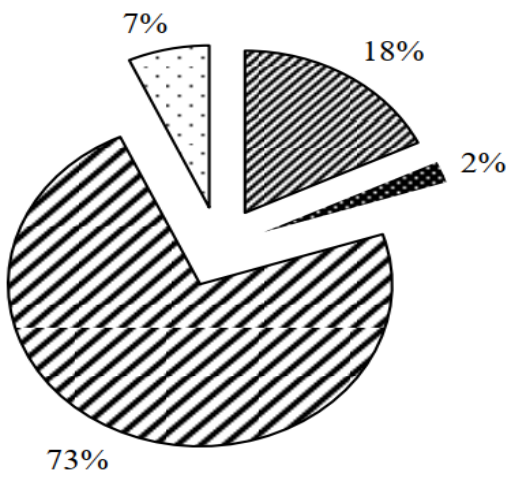

๑ Annual herb

a Grass

\Shrub

$\square$ Tree

Fig. 2. Life form of Natural Sal Forest.

\section{E. Composition of Species in Exotic Monoculture Plantation (EMP)}

A total of 2,827 plants were recorded which belong to 15 species and 13 families in EMP study area. Highest number of species was recorded from Leguminosae family. Butea monosperma, Dalbergia sissoo, Mimosa pudica species were found under Leguminosae family and eight numbers of individual plants have been found from this family in study area. Apocynaceae family includes 363 numbers of individual plants from Holarrhena pubescens species. Chromolaena odorata had 833 individuals from Asteraceae family in monoculture plantation study site. Dipterocarpaceae, Euphorbiaceae, Flacourtiaceae, Lauraceae, Malvaceae, Rubiaceae, Rutaceae, Sapindaceae, Tiliaceae and Verbenaceae families had single species each. Species richness was highest in M13 (9) and lowest was in 
M5 (2). Mean richness for the EMP was 4.47. Highest numbers of species diversity have been found in M11 (1.46) where lowest was noted in M5 (0.37). Mean species diversity index was 0.86 in EMP. Highest species evenness was in M11 (0.91) and lowest in M7 (0.32). The mean evenness has been found for EMP with 0.6. This indicates EMP have less equitable distribution of the species than adjacent NSF. Stem density was highest in M4 (519) and lowest in M11 (16). Mean stem density for EMP was 166.29 (Table 3).

TABLE 3: PLOT AREA, DIVERSITY, RICHNESS, EVENNESS AND DENSITY OF EXOTIC MONOCULTURE PLANTATION

\begin{tabular}{|c|c|c|c|c|c|c|c|c|c|c|c|c|c|c|c|c|c|}
\hline Plot ID & M 1 & M 2 & M 3 & M 4 & M 5 & M 6 & M 7 & M 8 & M 9 & $\begin{array}{l}\mathbf{M} \\
10 \\
\end{array}$ & $\begin{array}{l}\mathbf{M} \\
\mathbf{1 1} \\
\end{array}$ & $\begin{array}{l}\mathbf{M} \\
12 \\
\end{array}$ & $\begin{array}{l}\mathbf{M} \\
\mathbf{1 3} \\
\end{array}$ & $\begin{array}{l}M \\
14 \\
\end{array}$ & M 15 & M 16 & M 17 \\
\hline $\begin{array}{l}\text { Plot Area } \\
\left(\mathbf{m}^{2}\right)\end{array}$ & 100 & 100 & 100 & 100 & 100 & 100 & 100 & 100 & 100 & 100 & 100 & 100 & 100 & 100 & 100 & 100 & 100 \\
\hline $\begin{array}{l}\text { Diversity } \\
\text { (H') }\end{array}$ & 0.7 & 0.63 & 0.99 & 0.62 & 0.37 & 0.62 & 0.51 & 0.49 & 1.18 & 0.49 & 1.46 & 0.96 & 1.34 & 1.29 & 1 & 0.81 & 1.11 \\
\hline $\begin{array}{l}\text { Richness } \\
\text { (Nos.) }\end{array}$ & 3 & 3 & 7 & 5 & 2 & 3 & 5 & 4 & 5 & 2 & 5 & 5 & 9 & 5 & 5 & 4 & 4 \\
\hline $\begin{array}{l}\text { Evenness } \\
\left(\mathbf{J}^{\prime}\right)\end{array}$ & 0.64 & 0.57 & 0.51 & 0.39 & 0.53 & 0.56 & 0.32 & 0.35 & 0.73 & 0.71 & 0.91 & 0.6 & 0.61 & 0.8 & 0.62 & 0.58 & 0.8 \\
\hline $\begin{array}{l}\text { Density } \\
\text { (Nos.) }\end{array}$ & 88 & 137 & 382 & 519 & 81 & 40 & 390 & 418 & 144 & 31 & 16 & 180 & 153 & 48 & 105 & 42 & 53 \\
\hline
\end{tabular}

Note: M=Monoculture Sample Plot.

F. Composition of Shrub and Herb Species in Exotic Monoculture Plantation (EMP)

Shrub species was dominant among EMP study area. A total of eleven shrub species have been found from eleven families. Euphorbiaceae, Leguminosae, Verbenaceae, Sapindaceae, Flacourtiaceae, Apocynaceae, Lauraceae, Tiliaceae, Rubiaceae, Malvaceae and Rutaceae families had single species each in shrub group. In case of herbs, Chromolaena odorata and Mimosa pudica were found from Asteraceae and Leguminosae family respectively.

\section{G. Species Coverage in Exotic Monoculture Plantation (EMP)}

Most dominating understory plant species was Clerodendrum viscosum from Verbenaceae family which covered $49 \%$ of total vegetation in EMP study site. The stem density was 1,373 per $1700 \mathrm{~m}^{2}$ for Clerodendrum viscosum (Verbenaceae family) which was highest. Chromolaena odorata species form Asteraceae family had $29 \%$ of the total vegetation and density was 833 per $1700 \mathrm{~m}^{2}$ which was second dominatnt species in the study site. Holarrhena pubescens from Apocynaceae family was $13 \%$ and the density was 363 per $1700 \mathrm{~m}^{2}$. Antidesma sp. from Euphorbiaceae family, Butea monosperma and Dalbergia sissoo from Leguminosae family had the lowest percentage of vegetation cover with $0.04 \%$ of the total vegetation (Table 4).

TABLE 4: SPECIES COVERAGE IN EXOTIC MONOCUlture Plantation IN AN AREA OF $1700 \mathrm{~m}^{2}$

\begin{tabular}{cccc}
\hline Species & Family & $\begin{array}{c}\text { Density } \\
\text { (Count) }\end{array}$ & $\begin{array}{c}\text { Coverage } \\
(\%)\end{array}$ \\
\hline Clerodendrum viscosum & Verbenaceae & 1373 & 49 \\
Chromolaena odorata & Asteraceae & 833 & 29 \\
Holarrhena pubescens & Apocynaceae & 363 & 13 \\
Randia dumentorum & Rubiaceae & 162 & 6 \\
Microcos paniculata & Tiliaceae & 40 & 1 \\
Shorea robusta & Dipterocarpaceae & 23 & 1 \\
Flacourtia indica & Flacourtiaceae & 14 & 0.5 \\
Mimosa pudica & Leguminosae & 6 & 0.2 \\
Litsea monopetala & Lauraceae & 3 & 0.1 \\
Zanthoxylum rhetsa & Rutaceae & 3 & 0.1 \\
Erioglossum edulis & Sapindaceae & 2 & 0.1 \\
Urena lobata & Malvaceae & 2 & 0.1 \\
Antidesma sp. & Euphorbiaceae & 1 & 0.04 \\
Butea monosperma & Leguminosae & 1 & 0.04 \\
Dalbergia sissoo & Fabaceae & 1 & 0.04 \\
Total & & 2827 & 100 \\
\hline
\end{tabular}

\section{H. Life Forms of Exotic Monoculture Plantation (EMP)}

Tree, shrub, and annual herb were found in monoculture plantation study area. Study site was dominated by shrub and a total of 1,964 plants were recorded which represented $68 \%$ of the total understory vegetation cover. Annual herb (893) represented $31 \%$ of the total vegetation cover. Twenty four individual trees were counted in the study site which was $1 \%$ of total vegetation cover (Fig. 3).

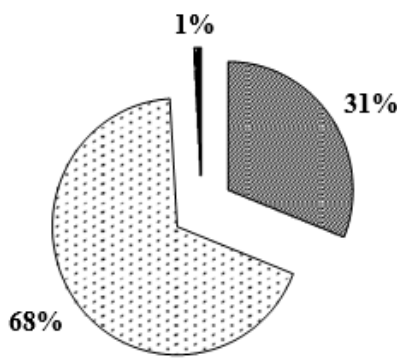

Annual Herb

$\square$ Shrub

-Tree

Fig. 3. Life form of Exotic Monoculture Plantation

\section{Species Composition in Natural Sal Forest (NSF) and Exotic Monoculture Plantation (EMP)}

A total of 44 species were recorded from the natural sal forest and exotic monoculture plantation. Out of that, 14 species were found in both forest types while 28 species found only in natural sal forest and two species in monoculture plantation site only (Table 5).

\section{J. Species Distribution in Exotic Monoculture Plantation (EMP) and Adjacent Natural Sal Forest (NSF)}

It was found that Randia dumentorum had highest position and $4^{\text {th }}$ in NSF and EMP area respectively. Clerodendrum viscosum was in second position which was dominant in EMP by existence as ranking first. Microcos paniculata and Melastoma malabathricum had the third and fourth position among the species and have been found in NSF study area. Swietenia mahagoni was in last position (Fig. 4). In the EMP site, Chromolaena odorata and Holannhena pubescens, came into existence as ranking second and third respectively. Dalbergia sissoo had the last position among the species ranking (Fig. 5). 

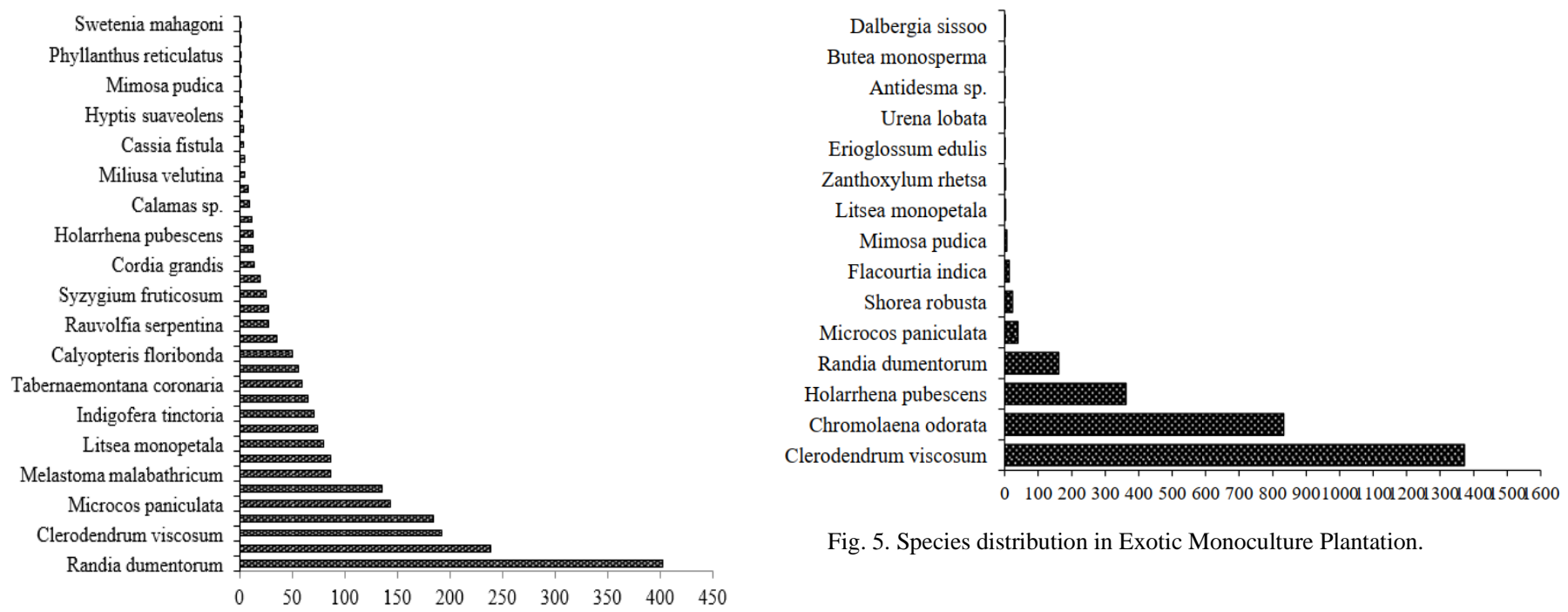

Fig. 4. Species distribution in Natural Sal Forest.

Fig. 5. Species distribution in Exotic Monoculture Plantation.

TABLE 5: SPECIES COMPOSITION IN NATURAL SAL FOREST AND EXOTIC MONOCULTURE PlantATION

\begin{tabular}{|c|c|c|c|c|c|}
\hline Local Name & Scientific Name & Life-form & Family & NSF & EMP \\
\hline Agra & Urena lobata & Shrub & Malvaceae & $\mathrm{Y}$ & $\mathrm{Y}$ \\
\hline Amloki & Phyllanthus embelica & Shrub & Euphorbiaceae & $\mathrm{Y}$ & $X$ \\
\hline Anoy & Un known & Shrub & Unknown & Y & $X$ \\
\hline Bajna & Zanthoxylum rhetsa & Shrub & Rutaceae & Y & $\mathrm{Y}$ \\
\hline Bat & Clerodendrum viscosum & Shrub & Verbenaceae & $\mathrm{Y}$ & Y \\
\hline Kutishor & Holarrhena pubescens & Shrub & Apocynaceae & $\mathrm{Y}$ & $\mathrm{Y}$ \\
\hline Bon Rongon & Ixora spectabilis & Shrub & Rubiaceae & $\mathrm{Y}$ & $\mathrm{X}$ \\
\hline Bon Tejpata & Melastoma malabathricum & Shrub & Melastomataceae & $\mathrm{Y}$ & $X$ \\
\hline Bonkori & Flacourtia indica & Shrub & Flacourtiaceae & $\mathrm{Y}$ & $\mathrm{Y}$ \\
\hline Boro Nil & Indigofera Tasmania & Shrub & Leguminosae & $\mathrm{Y}$ & $X$ \\
\hline Datoi & Microcos paniculata & Shrub/ Small tree & Tiliaceae & Y & $\mathrm{Y}$ \\
\hline Moilta & Glycosmis pentaphylla & Shrub & Rutaceae & $\mathrm{Y}$ & $\mathrm{X}$ \\
\hline Moish ful & Tabernaemontana coronaria & Shrub & Apocynaceae & $\mathrm{Y}$ & $X$ \\
\hline Mon Kata & Randia dumentorum & Shrub & Rubiaceae & $\mathrm{Y}$ & $\mathrm{Y}$ \\
\hline Nal moni & Un known & Shrub & Un known & $\mathrm{Y}$ & $X$ \\
\hline Nonta Gota & Antidemsa sp. & Shrub & Euphorbiaceae & $\mathrm{Y}$ & $\mathrm{Y}$ \\
\hline Sagol Nadi & Erioglossum edulis & Shrub & Sapindaceae & $\mathrm{Y}$ & $\mathrm{Y}$ \\
\hline Shorpogondha & Rauvolfia serpentina & Shrub & Apocynaceaea & $\mathrm{Y}$ & $X$ \\
\hline Un9 & Un known & Shrub & Un known & $\mathrm{Y}$ & $\mathrm{X}$ \\
\hline Hokin Jheu & Chromolaena odorata & Annual Herb & Asteraceae & $\mathrm{Y}$ & $\mathrm{Y}$ \\
\hline Ful Jharu & Thysanolaena maxima & Annual Herb & Poaceae & $\mathrm{Y}$ & $X$ \\
\hline Shoti & Curcuma zedaria & Annual Herb & Zingiberaceae & $\mathrm{Y}$ & $\mathrm{Y}$ \\
\hline Sitki & Phyllanthus reticulatus & Annual Herb & Euphorbiaceae & Y & $\mathrm{X}$ \\
\hline Kharajura & Litsea monopetala & Tree & Lauraceae & $\mathrm{Y}$ & $\mathrm{Y}$ \\
\hline Bohera & Terminalia bellirica & Tree & Combretaceae & $\mathrm{Y}$ & $\mathrm{X}$ \\
\hline Hijol & Barringtonia acutangula & Tree & Lecythidaceae & $\mathrm{Y}$ & $\mathrm{X}$ \\
\hline Gamar & Gmelina arborea & Tree & Verbenaceae & Y & $\mathrm{X}$ \\
\hline Gandhi gojar & Miliusa velutina & Tree & Annonaceae & $\mathrm{Y}$ & $\mathrm{X}$ \\
\hline Shonalo & Cassia fistula & Tree & Caesalpeniaceae & $\mathrm{Y}$ & $\mathrm{X}$ \\
\hline Shall & Shorea robusta & Tree & Dipterocarpaceae & $\mathrm{Y}$ & $\mathrm{Y}$ \\
\hline Shishu & Dalbergia sissoo & Tree & Fabaceae & $\mathrm{X}$ & $\mathrm{Y}$ \\
\hline
\end{tabular}

Note: NFS-Natural Sal Forest; EMP-Exotic monoculture plantation; Y-present, X-absence.

\section{K. Species Diversity between Natural Sal Forest and Exotic Monoculture Plantation}

Fig. 6 illustrated that there was remarkable difference of Shannon-Wiener diversity index and Mann-Whitney test $(U$ $=3, Z=4.95, P<.05)$ between EMP and adjacent NSF.
Species diversity was higher in NSF site compare to EMP site in at the entire sample plots. In NSF, mean ShannonWiener diversity was 2.09 while 0.86 for EMP. 


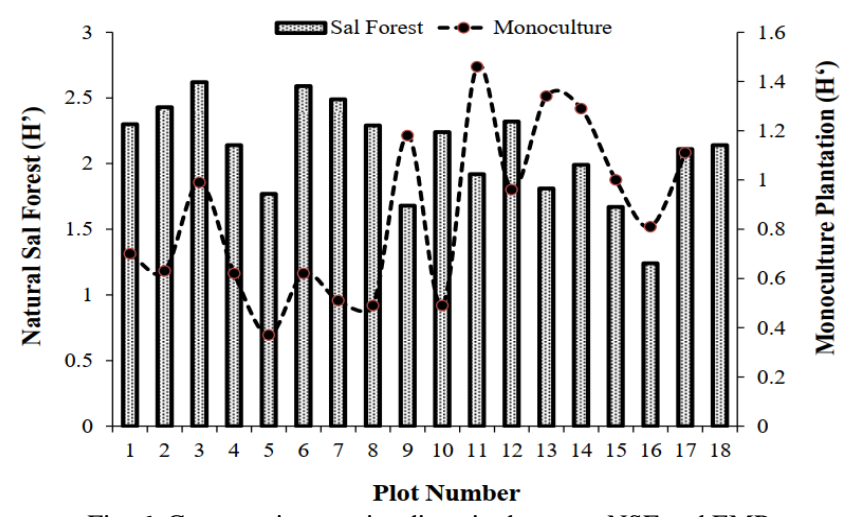

Fig. 6. Comparative species diversity between NSF and EMP

Different study revealed that NSF had significant higher tree species diversity index as compared to monoculture plantation in uttar prodesh, India [23]; Zimbabwe [24], Ethiopia and Kotiluoto (n.d) [25]. Natural forest showed higher value of biodiversity index in all vegetation layers as compared to monoculture plantation [26]-[29].

In contrast, some study revealed that the overall plant biodiversity was higher at monoculture plantation site than in natural forest [30], [31]. Lower anthropogenic disturbance than the natural forest could be the reason to get higher diversity in plantation site. But in my study area silvicultural operation like clear felling and cleaning have been carried out. Even the roots were uprooted. It could be another reason to get significant difference of diversity in my study area.

\section{Species Evenness between Natural Sal Forest (NSF) and Exotic Monoculture Plantation (EMP)}

The species evenness was higher in NSF as compared to EMP in all sample plot (Fig. 7), but it was not significant. Mean evenness was 0.79 for NSF while 0.60 for EMP. In contrast, with regards to herb group, evenness was significantly higher in NSF (0.52) as compared to EMP (0.03). Mann-Whitney test revealed $(U=37, Z=3.83, P<$ $.05)$ that there was significant difference of evenness in herb group. Similarly, Pourbabaei et al. [26] stated that species evenness was significantly higher in natural forest as compared to coniferous plantation which was conducted in Iran. Baktash [32] and Yirdaw [27] also stated that evenness was higher in natural forest as compared to monoculture plantation where Chauhan et al. [31] found opposite result. More number of individuals from two particular species (Chromolaena odorata and Clerodendrum viscosum) could reduce evenness in monoculture plantation site.

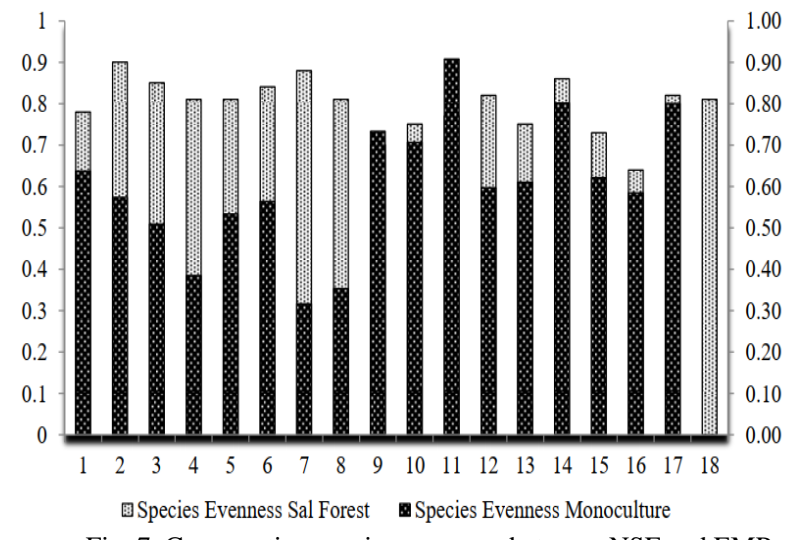

Fig. 7. Comparative species evenness between NSF and EMP.
M. Species Richness Comparison between Natural Sal Forest (NSF) and Exotic Monoculture Plantation (EMP)

There was notable difference of species richness between EMP and adjacent NSF. In NSF, mean species richness was 14.47 while 4.47 for EMP (Fig. 8). Mann-Whitney test revealed that $(U=2, Z=5.01, P<.05)$ there was significant difference of species richness between two forest types. Single species plantation has often been criticized for being associated with a low level of biodiversity in the ecosystem [32]. Similarly, the species richness was significantly high in natural forest as compared to monoculture plantation [23], ]24], [26], [31], [33]-[35]. Study conducted by Huttel \& Loumeto [36], stated that undergrowth species was relatively low under exotic monoculture plantation as compared to secondary forest. Study conducted in Iran by Taleshi [28] stated that species richness was higher in all vegetation layers in natural forest.

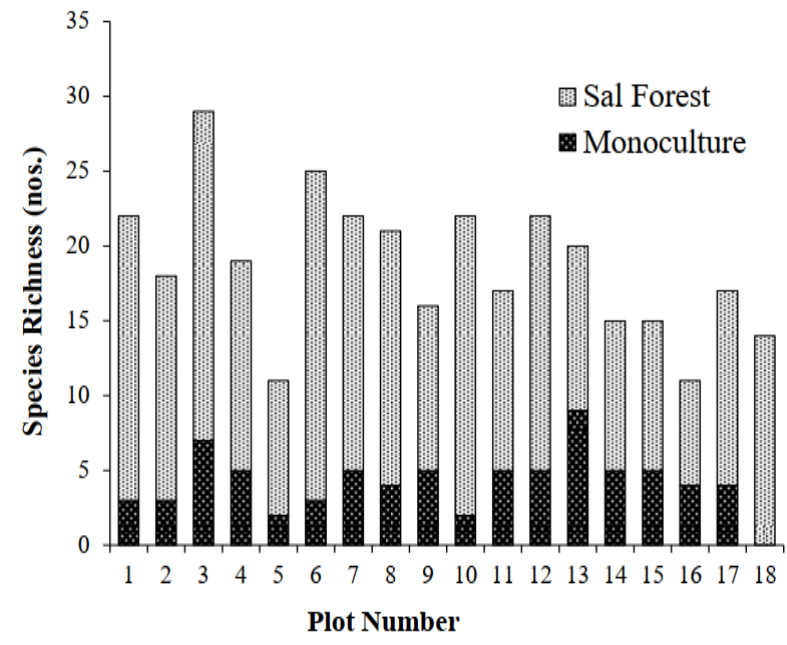

Fig. 8. Comparative species richness between NSF and EMP.

N. Stem Density (Nos.) between Natural Sal Forest and Monoculture Plantation

There was a little variation of stem density in different plot. Minimum (31) and Maximum (265) number of stem for NSF was recorded in plot number 16 and 17 respectively. Therefore, stem density for NSF lies within 31 to 265 where 16 to 519 for EMP (Fig. 9). The maximum (519) and minimum (16) number of stem density was noted in plot 4 and 11 respectively for EMP. EMP had higher stem density variation than NSF. The reason to get higher stem density variation is that two particular species had a greater number of individuals, but the total number of species was few. Moreover, in some plot the number of individuals was much higher than another plot. In fourth plot, total 519 numbers of individual were recorded from five species while 432 numbers of individuals were noted from Chromolaena odorata species. Similarly, in plot number seven, a total of 390 individuals were recorded from five species while 332 individuals were recorded from Clerodendrum viscosum species. In contrast, 16 individuals stem were recorded form five species in plot number eleven. It could be the reason to get much higher variation of stem density among two forest type. This also indicated that the species in not evenly distributed in EMP which support species evenness finding. 


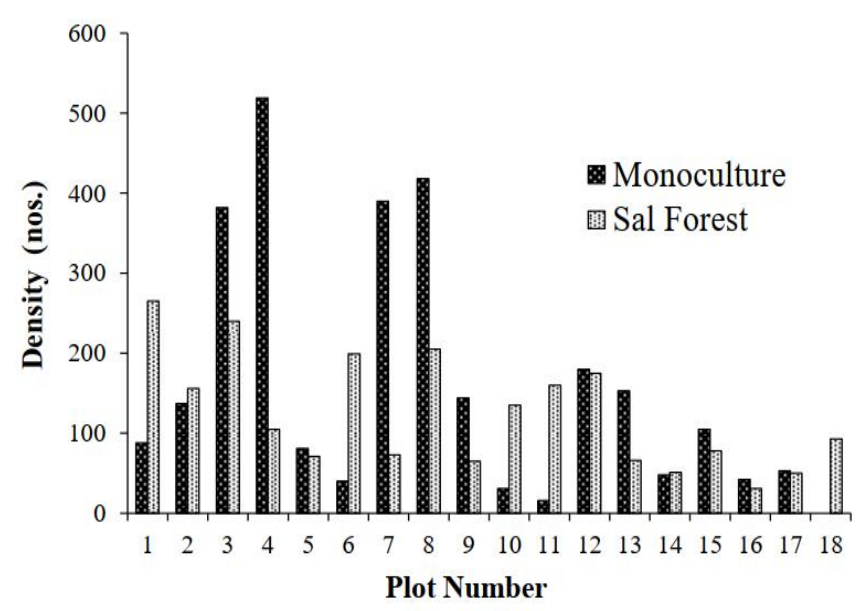

Fig. 9. Comparative species density between NSF and EMP.

O. Species Diversity Index according to Life Form in NSF and EMP with Jaccards' Similarity Index

Shannon-Wiener diversity index for the shrubs and herbs were 1.78 and 0.63 ; and 0.48 and 0.02 in NSF and EMP area correspondingly. NSF of the study area was more diverse than EMP area. Jaccards' similarity index allows us to quantify the degree of overlap between the species in two communities. Jaccards' similarity index was 0.36 for shrub and 0.30 for herb species in the study area. Result demonstrated that $36 \%$ of shrub and $30 \%$ of herb species were common and significantly varied between NSF and EMP. Around $70 \%$ of the species were common in both NSF and EMP with Eucalyptus camaldulensis. According to Yirdaw [27], 78\% of the species were similarly found in natural forest as well as in monoculture plantation in Ethiopia.

TABLE 6: DIVERSITY INDEX OF PLANT SPECIES OF NSF AND EMP WITH JACCARDS' SIMILARITIES INDEX

\begin{tabular}{ccccc}
\hline \multirow{2}{*}{ Diversity Index } & \multicolumn{2}{c}{ Shrub } & \multicolumn{2}{c}{ Herb } \\
\cline { 2 - 5 } & NSF & EMP & NSF & EMO \\
\hline Shannon diversity (H') & 1.78 & 0.63 & 0.48 & 0.02 \\
Jaccard's similarity Index & \multicolumn{2}{c}{0.36} & & 0.30 \\
\hline
\end{tabular}

\section{P. Mean Value of Species in Different Vegetation Layers} in Study Sites

For shrub vegetation layer, species diversity was found 1.78 and 0.63 for NSF and EMP. With respect to herb vegetation layer, species diversity of NSF (0.48) was much higher than EMP (0.03). Natural forest had the higher value of diversity in all vegetation layers than monoculture plantation (Table 7). Pourbabaei et al. [26] stated that, there were significant differences among diversity, evenness, and richness in all vegetation layers in different plantation area in Iran.

Species richness for shrub and herb were 10.56 and 3.26; and 2.00 and 0.78 for NSF and EMP vegetation layer separately. NSF had the higher value of richness in all vegetation layers (Table-7). Baktash [33], Taleshi [28] and Pourbabaei et al. [26] found the similar result. Although both types of forests were under same anthropogenic disturbance and similar microclimate environment but EMP had lower value of richness in all vegetation layers. It could be due to clear felling carried out in monoculture plantation and cleaning activities carried out for first two years. Moreover, it could be due to introduced species and single species plantation. They might have direct or indirect effect on native understory vegetation, which has been supported by Brockerhoff et al. [37].

Evenness of herb and shrub were 0.77 and 0.51 ; and 0.52 and 0.03 for NSF and EMP study area separately (Table 7). There was little difference of equitable species distribution between two types of forest.

TABLE 7: MEAN VALUE OF SPECIES DIVERSITY, RICHNESS AND EVENNESS IN DIFFERENT VEGETATION LAYERS

\begin{tabular}{cccc}
\hline \multirow{2}{*}{ Type } & Vegetation & \multicolumn{2}{c}{ Vegetation layer } \\
\cline { 3 - 4 } & type & Shrub & Herb \\
\hline Mean species & NSF & $1.78 \pm 0.39$ & $0.48 \pm 0.39$ \\
diversity & EMP & $0.63 \pm 0.45$ & $0.03 \pm 0.07$ \\
Mean value of & NSF & $10.56 \pm$ & $2 \pm 1.19$ \\
richness & EMP & 3.33 & \\
& $\mathrm{NSF}$ & $0.77 \pm 0.08$ & $0.78 \pm 0.65$ \\
Mean value of & $\mathrm{EMP}$ & $0.51 \pm 0.31$ & $0.03 \pm 0.11$ \\
evenness & & &
\end{tabular}

\section{CONCLUSION}

The study demonstrated in this research that, understory plant species diversity index in natural sal forest was higher than exotic monoculture plantation in all vegetation layer. One of the most universal features of natural systems is species richness. The number of different species cooccurring in a given area varies enormously from place to place. Species richness may differ substantially between areas in comparable environments. In the study sites, differences were observed in the number of trees, shrub and herb species, families, and vegetation composition between exotic monoculture plantation site and natural sal forest site which was much lower in exotic monoculture plantation area. Natural sal forest contributes higher richness of shrubs and herbs. Several herbs and shrubs were restricted only to natural forest of the study site. Therefore, it is not easy to avoid plantation activities. Before plantation activities with fast growing species people used to fell sal pole to get wood, fuel wood and another domestic use. In such a way exotic fast growing monoculture plantation is indirectly helping to decrease natural sal forest degradation by providing wood and fuel wood. In many places of natural sal forest area, forest land is degraded and illegally taken by the local community. Plantation activities can be done in those degraded land rather than replace with natural sal forest. Management may be implemented through plantation program with mixed species rather than a single species and indigenous species need to be considered. Clear felling system may be stopped to make way for plantation. It requires to do further research on compare understory plant species diversity between exotic monoculture plantation, mixed species plantation and plantation with native species in order to understand which type of forest providing more understory diversity.

\section{ACKNOWLEDGEMENT}

At first thanks to the almighty Allah. Authors were grateful to College of Natural Resources, Royal University of Bhutan and Bangladesh Forest Department for continues support during data collection and analysis. Sincere thanks to Ugyen Wangchuck Institute for Conservation and Environmental Research (UWICE) and South Asian 
Foundation (SAF) for financial support.

\section{REFERENCES}

[1] Uddin, M. B. (2013). Monoculture plantation in Bangladesh: Consequence for Biodiversity Conservation and Rurallivelihoods. <http://www.rufford.org/rsg/projects/mohammad_belal_uddin_0>.a ccessed 21. March 2014.

[2] Pancel, L. (1993). Tropical Forestry Handbook, Springel-Verlag, Berlin, Germany 809pp.

[3] Harley, M. J. (2002). Rational and method for conserving plantation forest. Forest Ecol Manag 155: 81-95.

[4] Asian Development Bank. (1993). Forestry Master Plan: Main plan93/2012, vol. 1, Ministry of Environment and Forest, Government of Bangladesh.162pp.

[5] Rahman, M. M., Rahman, M. M., Guogang, Z. and Islam, K. S. (2010). A review of the present threats to tropical moist deciduous Sal (Shorea robusta) forest ecosystem of central Bangladesh. Tropical Conservation Science vol. 3(1): 90-120.

[6] Hossain, M. K. (2005). Conversion of dipterocarp-dominant natura forest to short rotation plantation- unrecoverable threat to the native dipterocarps in Bangladesh, APAFRI, Malaysia.

[7] Motiur, M. R. (2006). Management and economics of homestead forest in Bangladesh. Unpublished doctoral dissertation, Ehime University, Matsuyama, Japan.

[8] Rashed, K. B. S. (1995). Participatory forestry as a strategy for reforestation In Bangladesh. Geojournal, 37(1), 39-44.

[9] Banglapedia. (2013). Sal forest, National encyclopedia of Bangladesh. <http://www.banglapedia search.com.bd>. Accessed 15 September 2013.

[10] Alam, M. K. (1995). Diversity in the Woody Flora of Sal Forests of Bangladesh. Bangladesh J.For.Sci., 24 (1), 41-52.

[11] Gain, P. (1998). The last forest of Bangladesh. Society for Environment and Human Development, Dhaka.

[12] Bangladesh Forest Department. (2004). Ministry of Environment and Forest, Government of Bangladesh.

[13] Alam, M., Furukawa, Y., Sarker, S. K. and Ahmed, R. (2008). Sustainability of Sal (Shorea robusta) forest in Bangladesh: past, present and future actions. International Forestry Review, 10(1):2937.

[14] Haque, N. (2007). Depletion of Tropical Forests with Particular Reference to Bangladesh. Our Nature, 8:313-3321.

[15] Asian Development Bank. (1992). Appraisal of the Upazila Afforestation and nursery development project in Bangladesh.

[16] Kabir, M. E. and Webb, E. L. (2005). Productivity and Suitability analysis of Social forestry woodlot species in Dhaka forest Division, Bangladesh. Forest Ecology and Management. 212(1/3): 243-252.

[17] GoB. (2001). National report on implementation on UN conservation on deforestation, Dhaka, Bangladesh.

[18] Wagner, R. G., Flynn, J. and Slovic, P. (1998). Acceptable practice in Ontario's forests: deference between the public forestry professionals. New Zealand for 16: 139-154.

[19] Hossain, M.K., Hossain, M., S. and Aryal, U. K. (1998). Initial growth performance of eight provenances of Acacia auriculiformis at Chittagong University Campus, Bangladesh. The Indian For, 124(4):256-258.

[20] http://en.climate-data.org/location/689859/, accessed on $2^{\text {nd }}$ June 2914.

[21] Shannon C.E. and Wiener W. (1963). The mathematical Theory of Communities. University of Illinois press, Urbana,111-117pp.

[22] Jaccard, Paul (1912), "The Distribution of the flora in the alpine zone", New Phytologist, 11 (2): 37 50, doi:10.1111/j.14698137.1912.tb05611.x.

[23] Bajpai, O., Kumar, A., Mishra, A. K., Sahu, N., Pandey, J., Behera, S. K. and Chaudhary, L. B. (2012). Re congregation of tree species of Katerniaghat wildlife sanctuary, Uttar Pradesh, India. Journal of Biodiversity and Environmental sciences, Vol.2, No.12, P.24-40.

[24] Tyynela, T. M. (2001). Species Diversity in Eucaliptus camaldulensis woodlots and woodland in northeastern Zimbabwe. New forest 22:239-257.

[25] Alem, S. (2006). Regeneration of Indigenous Woody Plants, Status of Soil Fertility and Quality of Coffee found in an Eucaliptus grandis Plantaion and the Adjacent Natural forest in SouthWestern Ethopia. <http://www.researchgate.net/publication/242216773>.accessed 8 October 2013

[26] Pourbabaei, H., Asgari, F., Reif, A. and Abedi, R. (2012). Effect of plantations on plant species diversity in the Darabkola, Mazandaran Province, Nort of Iran. BIODIVERSITAS, 13: 72-78

[27] Yirdaw, E. (2002). Restoration of the native woody - species diversity, using plantation species as foster trees, in the degraded highlands of Ethiopia. Unpublished master's thesis for master's degree. University on Helsinki, Finland.

[28] Taleshi, S. A. A. R. (2013). A comparative study on plant diversity in alder (Alnus subcordata) stands of natural and plantation areas. BIODIVERSITAS, 15(1):39-47.

[29] Sobuj, N. A. and Rahman, M. (2011). Comparison of Plant Diversity of Natural Forest and Plantations of Rema-Kalenga Wildlife Sanctuary of Bangladesh. Journal of Forest Science, 27(3): 127-134.

[30] Mandal, R. A., Yadav, B. K. V., Yadav, K. K., Dutta, I. C. and Haque, S. M. (2013). Biodiversity comparison of natural Shorea robusta mixed forest with Eucalyptus camaldulensis Plantation in Nepal. Scholars Academic Journal of Bio Sciences; 1(5): 144- 149.

[31] Chauhan, D. S., Singh, B., Chauhan, S., Dhanai, C. S. and Todaria, N. P. (2010). Regenaration and Plant Diversity of Natural and Planted Sal (Shorea rubasta.Gaertn.F.) Forest in the Terai-Bhabhar of Sohagibarwa Wildlife Sanctuary, India. Journal of American Science; 6(3).

[32] Montagnini, F. (1995). Mixed and pure forest plantations in the humid neotropics: A comparison of early groeth, past damage and establishment coasts. For Rev 74: 306-314.

[33] Baktash, L. (2003). Effect of plantation on plant diversity in the east of Guilan province, north of Iran. Unpublished doctoral dissertation, Guilan University, Somehsara. Iran

[34] Kamo, K., Vacharangkura, T., Tiyanon, S., Viriyabuncha, C., Nimpila, S. and Doangsrisen, B. (2001). Plant species Diversity in Tropical planted forests and implication for restoration of Forest Ecosystems in Sakaerat, Northeastern Thailand. JARQ, 36(2), 111118.

[35] Leopold, A. C. and Salazar, J. (2008). Understory Species Richness during Restoration of Wet Tropical Forest in Costa Rica. ECOLOGICAL RESTORATION 26:1.

[36] Huttel, C. and Loumeto, J. L. (2001). Effect of Exotic Tree Plantations and Site Management on Plant Diversity. In Effect of Exotic Tree Plantation on Plant Diversity and Biological soil Fertility in the Congo Savanna: With Special Reference to Eucalyptus, eds. F. B. Reversat, 1st edn., page:9, CIFOR.Indonesia.

[37] Brockerhoff, E. G., Jactel, H., Parrotta, J and Quine, C. P. (2008). Plantation forest and biodiversity: oxymoron or opportunity? Biodivers Cconserv, 17: 925-951.

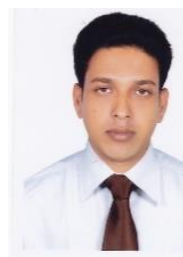

Md. Tauhidor Rahaman has completed Bachelo of Science in Forestry from the College of Natural Resources, Royal University of Bhutan. He has also received certificate course on GIS and Remote Sensing from the University of Philippine, Los Banos. He received training on Synthetic Aperture Radar (SAR) for Biomass Mapping and Forest Degradation from NASA in Nepal. Unmanned Ariel Vehicle (UAV) technologies had been adopted from the University of Twenty, Netherland. He developed expertise on Green House Gas Calculation using Ex-Act tools which have been organized by FAO, Thailand. He also learned Land Cover Mapping techniques using Google Earth Engine from ICIMOD, Nepal. He has developed further expertise on GhG estimation using IPCC software and guideline which have been taught by CBI (Capacity Building Initiative for Transparency) Project of FAO. Currently working for Bangladesh Forest Department as a Forester under the Ministry of Environment, Forest and Climate Change, Bangladesh. Currently Involve with Landcover mapping by Google Earth Engine Platform, GhG estimation in AFOLO Sector, UAV project in the Sundarban mangrove Forest.

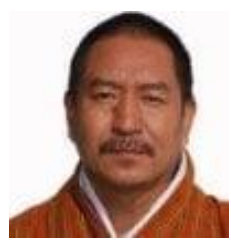

Professor D.B. Gurung complete his BSc and MSc from The University of Edinburgh, UK and Sherubtse College (Affiliated to University of Delhi, India), Bhutan in 1988 and 1996 respectively. He achieved PhD from ETH: Zurich, Switzerland in 2008. At present, he is a faculty member of College of Natural Resources, Royal University of Bhutan, Lobesa, Bhutan. Teaching in various programmes such as Statistics, Research Methodology, and Freshwater Ecology in Master and Undergraduate programmes. 


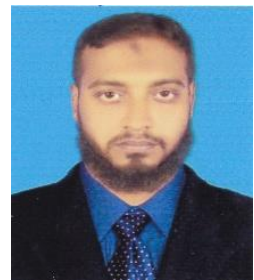

Md. Najmus Sayadat Pitol received B. S .c and MSc in Forestry and Wood Technology Discipline from Khulna University, Khulna in 2014 and 2017 respectively. Now he is working as Research

Officer, Mangrove Silviculture Division,

Bangladesh Forest Research Institute, Ministry of

Environment, Forest and climate change. 